\title{
Analysis of Content and In-Vitro Effect of Sodium Bicarbonate in Gripe Water Administered to Infants
}

\author{
Machchi Kinjal, and Mammen Denni* \\ School of Science, Navrachana University, Vasana-Bhayli Road, Vadodara, India
}

*Corresponding author: Mammen Denni, School of Science, Navrachana University, Vasana-Bhayli Road, Vadodara, India, Tel: +91 8980294648; E-mail: drdenni.mammen@gmail.com

Received: 03 Feb, 2020 | Accepted: 16 Mar, 2020 | Published: 20 Mar, 2020

Citation: Kinjal M, Denni M (2020) Analysis of Content and In-Vitro Effect of Sodium Bicarbonate in Gripe Water Administered to Infants. J Biochem Analyt Stud 4(1): dx.doi.org/10.16966/2576-5833.118

Copyright: (C) 2020 Kinjal M, et al. This is an open-access article distributed under the terms of the Creative Commons Attribution License, which permits unrestricted use, distribution, and reproduction in any medium, provided the original author and source are credited.

\begin{abstract}
Gripe water is an age-old formula normally administered to infants since birth to aid colic and acidity. The main constituent is sodium bicarbonate, and oil of seeds of dill or fennel, along with added sugar. This study aims to estimate the amount of sodium bicarbonate in different gripe water samples available in Indian markets. Determination of amount of sodium bicarbonate was performed using potentiometry. Only two of the analysed samples showed the amounts of sodium bicarbonate concordant with their label claims. Rest samples showed lower sodium bicarbonate contents. Sodium bicarbonate being a mild base could be responsible in countering acidity and colic in infants, though no proper study has been performed to support this claim. The effect of gripe water on a solution having $\mathrm{pH}$ similar to that of gastric juice has also been studied as a part of this study. The $\mathrm{pH}$ of the solution is found to increase by 0.2-0.4 units depending on the amount of sodium bicarbonate present in each sample. This change in $\mathrm{pH}$ could affect the digestion process of babies. The over-the-counter sale and unscrupulous use of gripe water need to be regulated.
\end{abstract}

Keywords: Gripe water; Sodium bicarbonate; pH; Potentiometry

\section{Introduction}

Gripe water was initially formulated as a mixture of dill seed oil, sodium bicarbonate, and alcohol along with other ingredients to soothe colic in babies. Alcohol was later removed from the list of ingredients due to its addiction forming effect and other long term effects on the digestive system of the infants. Sodium bicarbonate is still an important constituent in gripe water. Its weakly basic nature could be responsible in counteracting acidity problems in the stomach of infants. However, it could be a key factor that could cause alkalosis and milk- alkali syndrome [1].

Consumption of sodium bicarbonate need not always be safe since it can cause a condition called milk-alkali syndrome. In this condition the amount of calcium in the blood increases due to a high intake of milk calcium and sodium bicarbonate which is alkaline. Babies younger than six months which consume only breast milk, are at a greater risk of encounter this syndrome, if constantly given gripe water. Prolonged suffering due to this syndrome can affect the baby's kidneys. Premature babies and babies born with kidney problems are also advised not to be given sodium bicarbonate.

Gripe water contains added sugar which could adversely affect growing teeth in infants [2].

A very significant study has been conducted to ascertain the claim of the calming effect of gripe water on babies. Results of the study showed that gripe water administered babies showed increased occurrences of constipation, colic and vomiting, as compared to babies that were not given any doses of gripe water [3].

The unscrupulous and random use of gripe water is a cause of concern when administered without medical prescription. There are very scant studies available on the effects and constitution of gripe water samples administered to infants over generations.

\section{Materials and Methods}

Gripe water samples were procured from medical stores and online markets. Sodium bicarbonate, hydrochloric acid (35-38\%) and buffer tablets ( $\mathrm{pH} 4$ and 7) were all purchased from S. D. Fine Chemicals Limited, Mumbai, India.

\section{Construction of calibration graph of $\mathrm{NaHCO}_{3}$}

Standard solutions of $\mathrm{NaHCO}_{3}$ were prepared by dissolving 12.5 $\mathrm{mg}, 25 \mathrm{mg}, 50 \mathrm{mg}, 75 \mathrm{mg}$ and $100 \mathrm{mg} \mathrm{NaHCO}_{3}$ each in conductivity water, to a final volume of $50 \mathrm{~mL}$ in a volumetric flask.

Each standard solution ( $50 \mathrm{~mL}$ volume) taken in $250 \mathrm{~mL}$ beaker. The solution was stirred on magnetic stirrer, and $0.1 \mathrm{~N} \mathrm{HCl}$ solution was added in $1 \mathrm{~mL}$ aliquots and $\mathrm{pH}$ change was measured. The volume range that showed maximum change in $\mathrm{pH}$ was noted. The titration was repeated and the change in $\mathrm{pH}$ recorded with each addition of 
$0.1 \mathrm{~mL}$ of $0.1 \mathrm{~N} \mathrm{HCl}$ solution. Values of change in $\mathrm{pH}$ with respect to change in volume were calculated as $\Delta \mathrm{pH} / \Delta \mathrm{V}$. The first derivative plot of $\Delta \mathrm{pH} / \Delta \mathrm{V}$ was plotted against volume of $0.1 \mathrm{~N} \mathrm{HCl}$ solution added. The point of the graph, where maximum value of $\Delta \mathrm{pH} / \Delta \mathrm{V}$ was observed, was considered as equivalence point of the reaction [4].

Each sample was analyzed in triplicate. All solutions were analyzed on a digital $\mathrm{pH}$ meter (Equiptronics Instruments Pvt. Ltd., Mumbai, India) instrument using $\mathrm{pH}$ glass electrode (Toshniwal Instruments Pvt. Ltd., Ajmer, Rajasthan, India). The instrument was calibrated using buffer tablet solutions ( $\mathrm{pH} 4 \& 7$ ).

\section{Estimation of $\mathrm{NaHCO}_{3}$ content in various gripe water brands}

Each sample of gripe water $(5 \mathrm{~mL})$ diluted up to $50 \mathrm{~mL}$ in a volumetric flask. The solution was stirred constantly using magnetic stirrer. $0.1 \mathrm{~N} \mathrm{HCl}$ solution was added in $1 \mathrm{~mL}$ aliquots and $\mathrm{pH}$ change was measured. The volume range that showed maximum change in $\mathrm{pH}$ was noted. The titration was repeated by adding $0.1 \mathrm{~mL}$ of $0.1 \mathrm{~N}$ $\mathrm{HCl}$ solution and change in $\mathrm{pH}$ recorded. A graph of $\Delta \mathrm{pH} / \Delta \mathrm{V}$ was plotted against volume of $0.1 \mathrm{~N} \mathrm{HCl}$ solution added. The equivalence point of the graph was determined, where maximum $\Delta \mathrm{pH} / \Delta \mathrm{V}$ value was observed. Each sample was analysed in triplicate.

\section{Effect of gripe water on ph of artificial acidic solution}

Effect of gripe water on a solution having $\mathrm{pH}$ similar to gastric juice was studied. An artificial solution was prepared by dissolving $26.2 \mathrm{~mL}$ of hydrochloric acid along with $10 \mathrm{~g}$ each of $\mathrm{NaCl}$ and $\mathrm{KCl}$, and diluted up to mark in a 2 litre volumetric flask. The $\mathrm{pH}$ of the prepared solution was adjusted to 2.0 using $0.1 \mathrm{~N} \mathrm{NaOH}$ and $0.1 \mathrm{~N} \mathrm{HCl}$ solutions. Change in $\mathrm{pH}$ of $100 \mathrm{~mL}$ of this prepared solution on addition of 5 and $10 \mathrm{~mL}$ volumes of individual gripe water samples were recorded. Each sample was analysed in triplicate.

\section{Results, Discussion and Conclusion}

Analysis of different concentrations of sodium bicarbonate with respect to change in $\mathrm{pH}$ per unit volume of $0.1 \mathrm{~N} \mathrm{HCl}$ solution added yielded a calibration graph as shown in figure 1 . The graph showed a regression coefficient $\mathrm{r}^{2}=0.9995$, and the values of slope and intercept were 0.4053 and 2.0363 respectively. Values of equivalence points where maximum change of $\mathrm{pH}$ is observed per change in volume of $\mathrm{HCl}$ added, for each concentration of sodium bicarbonate has been shown in table 1.

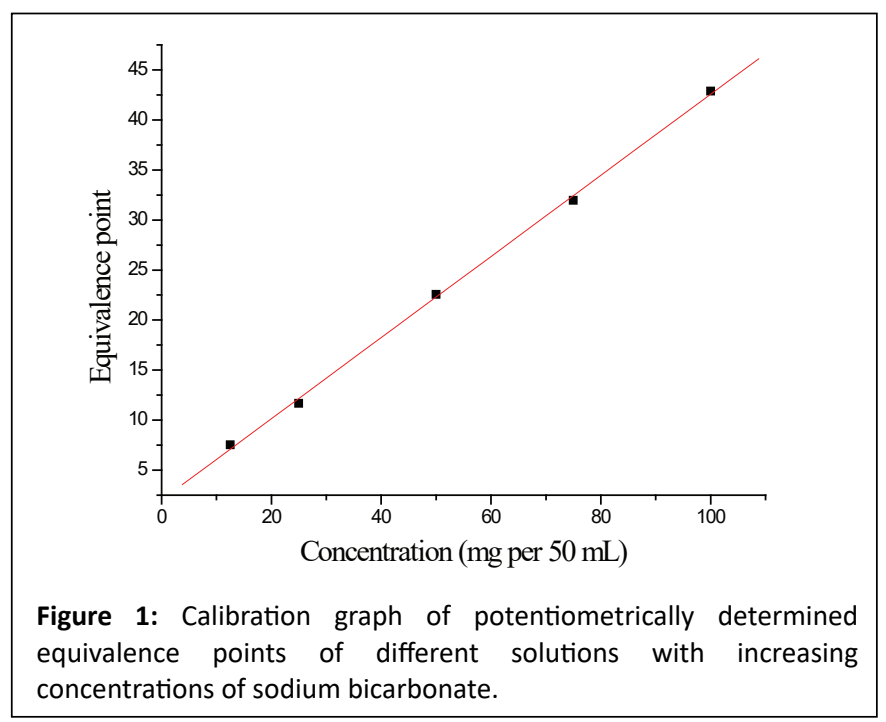

The Limits of Detection (LOD) and Quantitation (LOQ) were calculated to be $4.22 \mu \mathrm{g} / \mathrm{mL}$ and $12.79 \mu \mathrm{g} / \mathrm{mL}$ respectively. Analysis of the different gripe water samples on titration with $0.1 \mathrm{~N} \mathrm{HCl}$ solution gave results as shown in table 2. Only Woodward's and Dabur samples showed results concordant with the label claim. Samples of Babuline, Austro and Babit showed lower sodium bicarbonate content as compared to the label claims. Austro showed about $12 \%$ lesser sodium bicarbonate content, while Babuline and Babit samples showed almost $30 \%$ lesser sodium bicarbonate contents than their label claims.

Dosage of gripe water is $5 \mathrm{~mL}$ and $10 \mathrm{~mL}$ for infants and children. Therefore, effect on addition of these volumes of gripe water samples on a solution having $\mathrm{pH}$ similar to gastric juice have been shown in table 3. The $\mathrm{pH}$ of the solution is found to increase by $0.2-0.4$ units depending on the sodium bicarbonate content present in each sample. This change in $\mathrm{pH}$ could affect the digestion process of babies. Samples of Woodward and Dabur having higher sodium bicarbonate content showed more effect in $\mathrm{pH}$, while rest three samples showed lower change of $\mathrm{pH}$ due to lesser content of sodium bicarbonate.

Analysis of gripe water samples for their sodium bicarbonate content indicated that not all of them are true to their label claims. Only results of Woodward's and Dabur are in support of their label claims. Addition of the prescribed dosage of gripe water on artificial gastric juice solution indicates that there is change in $\mathrm{pH}$ of the

Table 1: Equivalence points of titrations of analyzed standard sodium bicarbonate solutions.

\begin{tabular}{|c|c|}
\hline $\begin{array}{c}\text { Amount of } \mathrm{NaHCO}_{3} \text { in } \\
\text { standard solution (mg) }\end{array}$ & Equivalence point* $(\mathrm{mL})$ \\
\hline 12.5 & $7.52 \pm 0.15$ \\
\hline 25 & $11.67 \pm 0.50$ \\
\hline 50 & $22.56 \pm 0.55$ \\
\hline 75 & $31.96 \pm 0.41$ \\
\hline 100 & $42.87 \pm 0.15$ \\
\hline
\end{tabular}

*Each value is an average of 3 readings.

Table 2: Estimation of $\mathrm{NaHCO}_{3}$ content in $5 \mathrm{~mL}$ of gripe water samples.

\begin{tabular}{|c|l|c|c|c|}
\hline \multirow{2}{*}{ S No. } & \multirow{2}{*}{$\begin{array}{c}\text { Brand of gripe } \\
\text { water }\end{array}$} & $\begin{array}{c}\text { Equivalence } \\
\text { point* }(\mathbf{m L})\end{array}$ & \multicolumn{2}{|c|}{ Content of $\mathbf{N a H C O}_{\mathbf{3}}(\mathbf{m g})$} \\
\hline 1 & Woodward's & $22.4 \pm 0.17$ & $50.24 \pm 0.42$ & 50 \\
\hline 2 & Dabur & $21.9 \pm 0.40$ & $50.16 \pm 1.24$ & 50 \\
\hline 3 & Babuline & $14.9 \pm 0.52$ & $31.73 \pm 1.30$ & 45 \\
\hline 4 & Austro & $14.63 \pm 0.15$ & $31.08 \pm 0.37$ & 40 \\
\hline 5 & Babit & $14.84 \pm 0.11$ & $31.57 \pm 0.28$ & 45 \\
\hline
\end{tabular}

*Each value is an average of 3 readings.

Table 3: Effect of gripe water on $\mathrm{pH}$ of $100 \mathrm{~mL}$ artificially prepared solution.

\begin{tabular}{|l|c|c|c|}
\hline $\begin{array}{c}\text { Brand of } \\
\text { gripe water }\end{array}$ & $\begin{array}{c}\text { pH before } \\
\text { addition }\end{array}$ & $\begin{array}{c}\mathrm{pH} \text { after addition } \\
\text { of } 5 \mathrm{~mL} \text { gripe water } \\
\text { sample* }\end{array}$ & $\begin{array}{c}\mathrm{pH} \text { after addition of } \\
\mathbf{1 0} \mathrm{mL} \text { gripe water } \\
\text { sample* }\end{array}$ \\
\hline Woodward's & 2.04 & $2.27 \pm 0.21$ & $2.75 \pm 0.35$ \\
\hline Dabur & 2.04 & $2.26 \pm 0.62$ & $2.71 \pm 0.56$ \\
\hline Babuline & 2.04 & $2.20 \pm 0.43$ & $2.48 \pm 0.74$ \\
\hline Austro & 2.04 & $2.18 \pm 0.84$ & $2.38 \pm 0.13$ \\
\hline Babit & 2.04 & $2.23 \pm 0.33$ & $2.53 \pm 0.19$ \\
\hline
\end{tabular}

*Each value is an average of 3 readings. 
solution. Similar effect on the actual pH of infant stomach can have adverse effect on digestion. This is in support of the fact why doctors today advise against the use of gripe water for infants. Over-thecounter sale and unscrupulous use of gripe water need to be regulated, since no scientific study has proved any benefits of administration of the age old recipe.

There are hardly any relevant studies conducted to study effects of gripe water on infants. However, in-vivo studies are required to be conducted to study actual effect of this age old remedy. Though considered good for digestion and to alleviate colic, there are still major concerns raised over the efficacy and safety of gripe water.

\section{Conflict of interest}

None

\section{References}

1. Adhisivam B (2012) Is gripe water baby friendly? J Pharmacol Pharmacother 3: 207-208.

2. Blumenthal I, Fenton D (1989) A gripe about gripe water. Arch Dis Child 64: 306-307.

3. Keerthi Jain, Dhandapany Gunasekaran, Chansekaran Venkatesh, Palanisamy Soundararajan (2015) Gripe water administration in infants 1-6 months of age- A cross sectional study. J Clin Diagn Res 9: SC06-SC08.

4. Al-Kamarany MA, Alwosaby AS, El Karbane M, Karrouchi K (2013) SFSTP guideline 1992- based validation of direct potentiometric method for quantification of sodium bicarbonate in baby's bliss gripe water available in Yemen. Int J Pharm Pharm Sci 5: 411-413. 